\title{
BENTUK-BENTUK PERUBAHAN SOSIAL DAN KEBUDAYAAN
}

\author{
Baharuddin
}

\begin{abstract}
ABSTRAK
Perubahan sosial budaya merupakan sebuah gejala berubahnya struktur sosial dan pola budaya dalam suatu masyarakat. Perubahan sosial budaya merupakan gejala umum yang terjadi sepanjang masa dalam setiap masyarakat. Perubahan itu terjadi sesuai dengan hakikat dan sifat dasar manusia yang selalu ingin mengadakan perubahan. Hirschman mengatakan bahwa kebosanan manusia sebenarnya merupakan penyebab dari perubahan.
\end{abstract}

Kata Kunci: sosial, budaya

\section{A. Pendahuluan}

Perubahan sosial budaya
merupakan sebuah gejala berubahnya
struktur sosial dan pola budaya dalam
suatu masyarakat. Perubahan sosial
budaya merupakan gejala umum yang
terjadi sepanjang masa dalam setiap
masyarakat. Perubahan itu terjadi sesuai
dengan hakikat dan sifat dasar manusia
yang selalu ingin mengadakan perubahan.
Hirschman mengatakan bahwa kebosanan
manusia sebenarnya merupakan
penyebab dari perubahan.
Perubahan sosial budaya terjadi
karena beberapa faktor. Di antaranya
komunikasi cara dan pola pikir masyarakat;
faktor internal lain seperti perubahan
jumlah penduduk, penemuan baru,
terjadinya konflik atau revolusi; dan faktor

eksternal seperti bencana alam dan perubahan iklim, peperangan, dan pengaruh kebudayaan masyarakat lain.

Ada pula beberapa faktor yang menghambat terjadinya perubahan, misalnya kurang intensifnya hubungan komunikasi dengan masyarakat lain; perkembangan IPTEK yang lambat sifat masyarakat yang sangat tradisional; ada kepentingan-kepentingan yang tertanam dengan kuat dalam masyarakat prasangka negatif terhadap hal-hal yang baru; rasa takut jika terjadi kegoyahan pada masyarakat bila terjadi perubahan hambatan ideologis dan pengaruh adat atau kebiasaan. 


\section{B. Hakekat Perubahan Sosial Budaya}

Perubahan dirasakan oleh hampir semua manusia dalam masyarakat. Perubahan dalam masyarakat tersebut wajar. Mengingatkan manusia memiliki kebutuhan yang tidak terbatas. Dalam kehidupan, seperti:

1. Peralatan dan perlengkapan hidup, yaitu mencakup pakaian, perumahan, alat-alat rumah tangga, senjata, alat produksi dan transportasi. Contoh, pada zaman nenek moyang kita memasak makanan dengan cara membakarnya, pada zaman sekarang (zaman modern) memasak makanan menggunakan alat modern seperti oven atau membeli makanan yang diawetkan.

2. Mata pencarian, seperti dalam sistem ekonomi meliputi pertanian, peternakan dan sistem produksi, sebagai contoh, kaum laki-laki bekerja dengan cara berburu atau pekerjaan lainnya. Sedangkan kaum perempuan tinggal dirumah mengurus rumah tangga dan mengasuh anak. Tetapi sekarang kaum perempuan dapat juga bekerja seperti pencaharian untuk kaum laki-laki.

3. Sistem kemasyarakatan, mencangkup sistem kekerabatan, organisasi politik, sistem hukum dan sistem perkawinan. Sebagai contohnya, pada masa kehidupan belum begitu kompleks orang-orang yang ada ikatan darah atau keluarga selalu hidup bersama dalam satu rumah. Saat ini ikatan masyarakat tidak hanya berdasarkan hubungan kekerabatan, tetapi juga karena profesi, dan hobi yang sama, seperti ikatan motor gede (MOGE), dll.

4. Bahasa, dahulu disampaikan secara lisan, sekarang bahasa dapat disampaikan melalui beragam media, seperti tulisan, sandi dan sebagainya.

5. Kesenian, mencakup seni rupa, seni suara, dan seni tari. Sebagai contoh, orang jawa menganggap bahwa rumahnyalah yang indah jika bernuansa gelap, sekarang masyarakat jawa banyak menyukai rumah yang bernuansa terang /pastel.

6. Sistem pengetahuan, berkaitan dengan teknologi. Contohnya, dahulu orangorang berpedoman pada alam atau peristiwa alam. Tetapi sekarang orangorang lebih cenderung menggunakan alat-alat modern,seiringnya berkembeng pengetahuan dan teknologi.

7. Serta religi/keyakinan, contohnya meyakini tentang adanya roh halus (roh leluhur) yang dapat dipercaya, namun sekarang manusia lebih berpikir logis dengan akal.

Perubahan-perubahan di atas sering disebut sebagai perubahan sosial dan perubahan budaya, karena proses berlangsungnnya dapat terjadi secara bersamaan, meskipun demikian perubahan sosial dan budaya sebenarnya terdapat 
perbedaan. Ada yang berpendapat bahwa perubahan sosial dapat diartikan sebagai sebuah transformasi budaya dan institusi sosial yang merupakan hasil dari proses yang berlangsung terus-menerus dan memberikan kesan positif atau negatif. Perubahan sosial juga diartikan sebagai perubahan fungsi kebudayaan dan prilaku manusia dalam masyarakat dari keadaan tertentu ke keadaan lain.

Berikut ini ada beberapa pengertian perubahan sosial yang dikemukakan oleh para ahli sosiologi

1. Max Iver mengemukakan bahwa perubahan sosial berarti perubahan dalam hubungan sosial atau sebagai perubahan terhadap keseimbangan hubungan sosial (dalam buku A Text Book Fo Sociology).

2. Gillin menyatakan bahwa perubahan sosial merupakan pariasi cara-cara hidup yang telah diterima baik karena perubahan kondisi geografis, kebudayaan material, komposisi penduduk, idiologi, maupun karena adanya difusi ataupun penemuan baru dalam masyarakat (http://id.wakipedia. com/wiki/ perubahan sosial budaya).

3. Kingsley Davis mengemukakan perubahan sosial sebagai perubahan yang terjadi dalam stuktur dan fungsi masyarakat (dalam buku Human Society)
4. Selo Sumardjan mengartikan bahwa perubahan sosial adalah perubahan pada lembaga - lembaga kemasyarakatan di dalam satuan masyarakat (dalam buku perubahan sosial di Yogyakarta). Jadi dapat disimpulkan bahwa perubahan sosial adalah perubahan struktur dan fungsi sosialnya. Oleh karena itu, perubahan sosial berkaitan erat dengan perubahan kebudayaan dan seringkali perubahan sosial berkaitan pada perubahan budaya. Jika pengertian perubahan sosial telah diuraikan di atas maka apakah yang dimaksud dengan perubahan sosial budaya itu? Berikut ini pengertian perubahan sosial budaya dari beberapa tokoh.

1. Max Weber berpendapat bahwa perubahan sosial budaya adalah perubahan situasi dalam masyarakat sebagai akibat adanya ketidaksesuaian unsur-unsur (dalam buku Sociological Writings).

2. W. Kornblum berpendapat bahwa perubahan sosial budaya adalah perubahan sustu budaya masyarakat secara bertahap dalam jangka waktu lama (dalam buku Sociology in Changing World).

\section{Perbedaan dan Hubungan Perubahan Sosial dan Budaya}

Perubahan sosial dan budaya memiliki keterkaitan yang sangat erat 
sekali. Sesuai perubahan sosial pastilah akan memberikan pengaruh terjadinya perubahan budaya. Suatu perubahan kebudayaan mencakup semua bagiannya, yaitu kesenian, ilmu pengetahuan, teknologi filsafat, dan lain sebagainya. Bagian dari budaya tersebut tidak dapat lepas dari kehidupan sosial manusia dalam masyarakat. Tidak mudah menentukan garis pemisah antara perubahan sosial dan perubahan budaya, karena tidak ada masyarakat yang tidak ada kebudayaan, sebaliknya, tidak mungkin ada kebudayaan yang tidak terjelma (masuk) dalam masyarakt. Dengan kata lain, perubahan sosial dan budaya memiliki satu aspek yang sama, yaitu kedua-duanya bersangkut paut dengan suatu penerimaan cara-cara baru atau suatu perbaikan tentang cara suatu masyarakat dalam memenuhi kebutuhannya.

Meskipun perubahan sosial dan budaya memiliki hubungan atau keterkaitan yang erat, namun keduanya juga memiliki perbedaan. Perbedaan antara perubahan sosial dan budaya dapat dilihat dari arahnya, perubahan sosial merupakan perubahan dalam segi struktur dan hubungan sosial, sedangkan perubahan budaya merupakan perubahan dalam segi budaya masyarakat. Perubahan sosial terjadi dalam segi distribusi kelompok umur, jenis pendidikan, dan tingkat kelahiran penduduk.
Perubahan budaya meliputi penemuan dan penyebaran masyarakat, perubahan konsep nilai susila dan mortalitas, bentuk seni baru dan kesetaraan gender.

Terkadang perubahan sosial dan budaya mengalami tumpang tindih, sebagai contoh saat ini masyarakat meningkatkan adanya kesamaan gender berhubungan dengan perubahan yang seperangkat norma budaya dan fungsi peran kaum laki-laki dan perempuan secara sosial. Untuk mengatasi ketumpang tindihan tersebut maka sering kita gunakan istilah perubahan sosial budaya untuk mencakup kedua perubahan tersebut. Dengan demikian, suatu perubahan dikaitkan sebagai perubahan sosial budaya apabila memiliki karakteristik sebagai berikut:

1. Tidak ada masyarakat yang perkembangannya berhenti karena setiap masyarakat mengalami perubahan secara cepat ataupun lambat.

2. Perubahan yang terjadi pada lembaga kemasyarakatan akan diikuti perubahan pada lembaga sosial yang ada

3. Perubahan yang berlangsung cepat biasanya akan mengakibatkan kekacauan sementara karena orang akan berusaha untuk menyesuaikan diri dengan perubahan yang terjadi. 
4. Perubahan tidak dapat dibatasi pada bidang kebendaan atau spiritual saja karena keduanya saling berkaitan.

\section{Bentuk-Bentuk Perubahan Sosial dan Kebudayaan}

Perubahan sosial yang terjadi dalam masyarkat atas beberapa bentuk sebagai berikut:

\section{Perubahan Evolusi dan Revolusi}

a. Perubahan evolusi adalah perubahan - perubahan sosial yang terjadi dalam proses yang lambat dan dalam waktu yang cukup lama tanpa ada kehendak tertentu dari masyarakat yang bersangkutan. Perubahan ini terjadi karena adanya dorongan dari usaha masyarakat untuk menyesuaikan diri terhadap kebutuhan - kebutuhan hidup terhadap perkembangan masyarakat pada waktu tertentu, misalnya, adanya modernisasi mengakibatkan perubahan pada sistem transportasi, dan sistem perbankan.

b. Perubahan revolusi adalah perubahan yang berlangsung secara cepat dan tidak ada kehendak atau direncanakan sebelumnya. Perubahan ini terjadi bisa karena sudah direncanakan sebelumnya atau tidak sama sekali. Revolusi biasanya diawali oleh ketegangan- ketegangan atau konflik dalam masyarakat. Misalnya, peristiwa terjadinya revolusi industri di inggris, dimana terjadi pada tahap produksi yang awalnya tanpa mesin, kemudian berubah menjadi tahap produksi menggunakan mesin.

2. Perubahan yang Dikehendaki dan Tidak Dikehendaki

perubahan yang dikehendaki ialah disebut dengan perubahan yang direncanakan dan perubahan yang tidak dikehendaki disebut perubahan yang tidak direncanakan.

a. Perubahan yang direncanakan adalah perubahan yang terjadi karena adanya perkiraan atau perencanaan oleh pihakpihak yang menghendaki perubahan tersebut (agen of change). Misalnya, perubahan yang dilakukan pemerintah melalui perundang-undangan untuk melarang anggota dewan merangkap sebagai pegawai negeri sipil.

b. Perubahan yang tidak direncanakan ialah perubahan yang berlangsung di luar kehendak dan pengawasan masyarakat. Perubahan ini biasanya menimbulkan pertentangan yang merugikan kehidupan masyarakat yang bersangkutan. Misalnya, kecenderungan untuk mempersingkat prosesi adat pernikahan yang memerlukan biaya besar dan waktu lama, meskipun 
perubahan ini tidak dikehendaki masyarakat tetapi tidak sanggup untuk menghindarinya.

\section{Perubahan kecil dan Besar}

Perubahan kecil dan besar memiliki batas-batas yang sangat relatif. Perubahan kecil diartikan perubahan yang terjadi pada unsur struktur sosial yang tidak membawa pengaruh langsung atau berarti bagi masyarakat. Contohnya, perubahan model pakaian, rambut, sepatu, dan lain-lain yang tidak berpengaruh signifikan terhadap masyarakat keseluruhan sebab tidak menimbulkan perubahan pada lembaga kemasyarakatan.

Perubahan besar adalah sebuah perubahan yang terjadi pada unsur-unsur struktur sosial yang memberi pengaruh langsung atau berarti bagi masyarakat. Contohnya, pengelolaan pertanian dengan pemakain alat pertanian dari mesin (traktor) pada masyarakat agraris merupakan perubahan yang membawa pengaruh besar, perubahan sosial budaya tidak mungkin terjadi dengan sendirinya. Perubahn sosial budaya dapat terjadi karena ada penyebabnya. Kemungkinan perubahan terjadi karena adanya sesuatu yang baru dan sesuatu yang lama dianggap tidak berfungsi lagi.

\section{E. Penyebab dan Faktor Terjadinya Perubahan Sosial Budaya}

1. Perubahan dari dalam Masyarakat

Perubahan dari dalam masyarakat terbagi sebagai berikut:

a. Perubahan Penduduk: Perubahan yang dimaksud adalah perubahan yang dikarenakan bertambah dan berkurangnya jumlah penduduk. Pertambahan penduduk akan menyebabkan perubahan pada tempat tinggal. Dimana tempat tinggal yang semulanya terpusat pada lingkungan kerabat akan berubah atau terpancar karena faktor pekerjaan. Berkurangnya penduduk juga akan menyebabkan perubahan sosial budaya. Contohnya pada perubahn penduduk dalam program transmigrasi dan urbanisasi.

b. Pemberontakan atau Revolusi: Pemberontakan akan menyebabkan perubahan sosial budaya, contohnya pemberontakan G 30 S/PKI. Pemberontakan G 30 S/PKI pada tahun 1965 membawa perubahan terutama dalam sistem politik Indonesia sehingga dilarangnya ajaran komunis di Indonesia. Pelarangan ajaran komunis di Indonesia ini disebabkan karena tidak sesuai dengan nilai-nilai pancasila yang menjadikan dasar hidup bermasyarakat, berbangsa, 
dan bernegara bagi bangsa Indonesia.

c. Peranan Nilai yang Diubah: Perubahan juga dapat disebabkan berubahnya perana nilai di masyarakat. Misalnya, sosialisasi program keluarga berencana mampu untuk menghambat pertambahan penduduk. Contohnya sebelum ada program keluarga berencana dari pemerintah, masyarakat yang sudah berkeluarga akan terlihat cenderung meningkatkan mempunyai anak banyak, namun setelah ada sosialisasi program keluarga berencana masyarakat tumbuh kesadaran untuk membatasi kelahiran anak demi masa depan dan kesejateraan anak itu sendiri.

d. Peranan Tokoh Kharismatik: Tokoh kharismatik adalah tokoh yang disegani, dihormati dan diteladani oleh masyarakat. Peranan tokoh kharismatik membawa pengaruh dalam perubahan kehidupan masyarakat. Misalnya, Soekarno sebagai presiden $\mathrm{Rl}$ memiliki kharismatik dihadapan rakyat karena keahliannya dapat berpidato dengan baik.

e. Penemuan Baru: Adanya penemuan baru dalam kehidupan masyarakat baik itu berupa ilmu pengetahuan maupun teknologi mempengaruhi dan membawa perubahan dalam masyarakat. Penemuan mobil misalnya, penemuan tersebut akan membawa perubahan kebudayaan dan sosial masyarakat. Dalam masyarakat akan terbentuk status social / berdasarkan harta (mobil) yang dimiliki, orang yang tidak memiliki mobil bisa dianggap status sosialnya lebih rendah dibandingkan dengan orang yang memiliki mobil. Selanjutnya, orang yang memiliki sebuah mobil bisa dianggap lebih rendah statusnya dibandingkan orang yang memiliki lebih dari satu mobil.

\section{Perubahan dari Luar Masyarakat} Perubahan sosial budaya juga dapat terjadi karena unsur dari luar masyarakat seperti faktor geografis, kebudayaan, dan politik. Pengaruh luar masyarakat merupakan hal yang wajar dalam perubahan sosial budaya masyarakat. Pengaruh dari luar masyarakat tersebut adalah sebagai berikut:

a. Pengaruh Lingkungan Alam: Pengaruh lingkungan alam sangat berpengaruh dalam terjadinya perubahan sosial budaya. Misalnya, tanah yang subur dapat berguna untuk lahan pertanian sehingga masyarakat di daerah tersebut 
memiliki usaha sebagai petani. Kebudayaan di tanah suburpun tidak lepas dari kehidupan sosial sebagai petani sehingga kebudayaan tetap akan berhubungan dengan bidang pertanian.

b. Kebudayaan Masyarakatan lain: Kontak kebudayaan antar masyarakat mempunyai dampak yang positif dan negatif. Contohnya, kontak kebudayaan bangsa Indonesia dengan bangsa Barat (Eropa). Pengaruh positif berupa transfer ilmu pengetahuan dan teknologi, sedangkan pengaruh negatif berupa pola hidup kebaratbaratan (westernis) sekelompok anak muda.

c. Peperangan: Peperangan akan menyebabkan pengaruh negatif terhadap sebuah aspek kehidupan masyrakat. Misalnya, perang Irak yang membawa derita dan trauma berkepanjangan bagi rakyat Irak. Selaian disebabkan oleh beberapa hal di atas, suatu perubahan sosial budaya terjadi karena adanya faktor yang menyebabkannya. Faktor yang menyebabkan perubahan sosial budaya terdiri atas faktor pendorong dan penghambat.
3. Faktor Pendorong Perubahan Sosial Budaya

a. Timbunan kebudayaan dan penemuan baru. Kebudayaan dalam masyarakat selalu mengalami penimbunan dan penumpukan, yaitu budaya masyarakat semakin beragam dan bertambah. Bertambah dan beragamnya budaya ini umumnya disebabkan oleh adanya penemuan baru dalam masyarakat.

b. Perubahan jumlah penduduk. Bertambah dan berkurangnya jumlah penduduk suatu daerah mengakibatkan perubahan struktur masyarakat terutama lembaga kemasyarakatannya.

c. Pertentangan atau Konflik. Pertentangan yang terjadi dalam masyarakat karena kemajemukan menyebabkan perubahan sosial. Dalam masyarakat yang heterogen, sifat individualistis masih lekat sehingga satu sama lainnya tidak memiliki hubungan yang dekat. Padahal sumber kebutuhan semakin terbatas. Persaingan yang terjadi untuk memperebutkan segala sumber kebutuhan mendorong masyarakt untuk berkreasi menciptakan 
alternatif pemenuhan sumber kebutuhan.

d. Terjadinya Pemberontakan atau Revolusi. Perubahan sosial budaya dapat bersumber dari luar masyarakat itu sendiri diantaranya sebab yang berasal dari lingkungan alam fisik di sekitar manusia, seperti bencana alam dan peperangan.

e. Sistem terbuka lapisan masyarakat: Masyarakat dengan sistem lapisan yang terbuka cenderung lebih mudah mengalami perubahan dari pada dengan sistem lapisan tertutup. Masyarakat akan selalu cenderung memberikan kesempatan berkarya bagi manusia - manusia yang potensial.

f. Sifat menghargai hasil karya seseorang dan keinginan untuk maju. Sikap masyarakat yang mau menghargai hasil karya orang lain akan membuat orang terdorong untuk melakukan penelitian. Dengan demikian itu semua akan menghasilkan sebuah karya yang berguna bagi masyarakat.

g. Sistem pendidikan formal yang maju: Kualitas pendidikan yang tinggi maupun mengubah pola pikir. Masyarakat yang memiliki pendidikan tinggi akan lebih rasional dalam berpikir dan bertindak.

h. Orientasi ke masa depan: Keinginan untuk memperoleh masa depan yang lebih baik akan mendorong perubahan sosial budaya masyarakat.

i. Akulturasi: Akulturasi merupakan pertemuan dua kebudayaan dari bangsa yang berbeda dan saling mempengaruhi. Peroses akulturasi berlangsung lama dan terusmenerus. Proses ini berkaitan pada perpaduan kebudayaan sehingga pola budaya semua akan berubah.

j. Asimilasi: Definisi Asimilasi adalah perpaduan dua kebudayaan yang berbeda secara berangsur angsur berkembang sehingga memunculkan budaya baru.

4. Faktor Penghambat perubahan sosial budaya

a. Perkembangan ilmu pengetahuan yang terhambat

b. Sikap masyarakat yang sangat tradisional

c. Kurangnya hubungan dengan masyarakat lain

d. Adanya kepentingan-kepentingan yang telah tertanam kuat 
e. Rasa takut dengan adanya kegoyahan pada integrasi kebudayaan

f. Hubungan yang bersifat idiologis

g. Adat atau kebiasaan

h. Prasangka terhadap hal-hal baru dan menilai bahwa hidup ini buruk, susah, dan tidak mungkin diperbaiki.

\section{Dampak perubahan Sosial Budaya}

Faktor-faktor perubahan sosial budaya tersebut secara langsung atau tidak langsung akan memberikan dampak negatif dan fositip. Kita tidak khawatir jika perubahan yang terjadi bersifat positif karena perubahan positif akan memberikan pengaruh baik. Namun, kita harus berhati-hati dengan dampak negatif yang menonjol.

a. Akibat positif: Perubahan dapat terjadi apabila masyarakat dengan kebudayaan mampu menyesuaikan diri dengan gerak perubahan. Keadaan masyarakat yang memiliki kemampuan dalam menyesuaikan diri disebut adjusment, sedangkan bentuk penyesuaian masyarakat dengan gerak perubahan disebut integrasi.

b. Akibat Negatif: Akibat negatif terjadi apabila masyarakat dengan kebudayaannya tidak mampu menyesuaikan diri dengan gerakan perubahan. Ketidak mampuan dalam menyesuaikan diri sendiri dengan perubahan disebut maladjusment. Maladjusment akan menimbulkan disintegrasi.

\section{F. Perilaku Kritis Adanya Pengaruh Perubahan Sosial Budaya}

Penerimaan masyarakat pada perubahan sosial budaya dilihat dari perubahan sikap masyarakat yang bersangkutan. Jika perubahan sosial budaya tersebut tidak mempengaruhi keberadaan nilai dan norma yang sudah ada di masyarakat maka sikap masyarakat akan positif. Namun, jika perubahan sosial budayanya tersebut menyimpang atau mempengaruhi nilai dan norma yang benar maka sikap masyarakat akan negatif. Contoh sikap masyarakat adanya perubahan sosial budaya adalah sebagai berikut:

1. Aksi protes adalah pergolakan massa yang bersifat umum sebagai perwujudan rasa tidak puas terhadap keputusan-keputusan dan kejadian di masyarakat.

2. Kenakalan remaja adalah suatu perbuatan antisosial yang dilakukan oleh anak remaja. Dimana kenakalan remaja muncul dari keluarga yang tidak harmonis karena disebabkan kurangnya pengawasan dalam keluarga. Bentukbentuk kenakalan remaja adalah 
membolos sekolah, berkelahi, minumminuman keras, dan mengebut di jalan raya.

3. Kriminalitas adalah pelangaran norma hukum yang dilakukan seseorang dan dapat diancam sangsi pidana. Kriminalitas adalah disebabkan oleh pertentangan kebudayaan, perbedaan ideologi politik, perbedaan pendapat dari mental yang tidak stabil.

Jadi perubahan sosial dan budaya membawa dampak positif dan negatif terhadap kehidupan. Kita harus waspada terhadap hal-hal yang menimbulkan perubahan yang mengarah ke hal negatif. Oleh sebab itu kita harus mempunyai sikap tegas menolak terhadap perubahan yang membawa ke arah negatif. Kita dapat mengambil pengaruh positifnya dengan tepat berpedoman pada nilai dan norma masyarakat. Adapun hal-hal yang dapat dilakukan terhadap pengaruh dari luar. Antara lain sebagai berikut:

1. Mengambil pengaruh positif budaya Barat, seperti tepat waktu (disiplin), bekerja keras, dan rajin belajar berbagai ilmu pengetahuan.

2. Membentengi diri dengan ilmu agama

3. Mengenal dan mencintai kebudayaan sendiri serta berusaha melestarikannya.

\section{G. Perubahan Sosial Budaya}

Perubahan sosial adalah perubahan-perubahan yang terjadi pada masyarakat yang mencakup perubahan dalam aspek-aspek struktur dari suatu masyarakat, atau karena terjadinya perubahan dari faktor lingkungan, dikarenakan berubahnya sistem komposisi penduduk, keadaan geografis, serta berubahnya sistem hubungan sosial, maupun perubahan pada lembaga kemasyarakatannya. Perubahan ini menyangkut pada seluruh segmen yang terjadi di masyarakat pada waktu tertentu. Perubahan sosial dalam masyarakat bukan merupakan sebuah hasil atau produk tetapi merupakan sebuah proses. Perubahan sosial merupakan sebuah keputusan bersama yang diambil oleh anggota masyarakat.

Konsep dinamika kelompok menjadi sebuah bahasan yang menarik untuk memahami perubahan sosial. Berdasarkan besar kecilnya pengaruh yang terjadi pada masyarakat, perubahan sosial dibagi menjadi 2, yakni perubahan sosial yang besar dan perubahan sosial yang kecil. Perubahan sosial yang besar pada umumnya adalah perubahan yang akan membawa pengaruh yang besar pada masyarakat. Misalnya, terjadinya proses industrialisasi pada masyarakat yang masih agraris. Di sini lembagalembaga kemasyarakatan akan terkena 
pengaruhnya, yakni hubungan kerja, sistem pemilikan tanah, klasifikasi masyarakat, dan lainnya. Sedangkan perubahan sosial yang kecil adalah perubahan-perubahan yang terjadi pada unsur-unsur struktur sosial yang tidak membawa akibat yang langsung pada masyarakat. Misalnya, perubahan bentuk potongan rambut pada seseorang, tidak akan membawa pengaruh yang langsung pada masyarakat secara keseluruhan. Hal ini dikarenakan tidak akan menyebabkan terjadinya perubahan pada lembagalembaga kemasyarakatan.

Perubahan sosial budaya adalah sebuah gejala berubahnya struktur sosial dan pola budaya dalam suatu masyarakat. Perubahan sosial budaya merupakan gejala umum yang terjadi sepanjang masa dalam setiap masyarakat. Perubahan itu terjadi sesuai dengan hakikat dan sifat dasar manusia yang selalu ingin mengadakan perubahan. Dalam kehidupan nyata, perubahan sosial yang terjadi pada masyarakat, pasti akan terjadi. Setiap segmen masyarakat hendaknya fleksibel terhadap perubahan yang akan terjadi baik cepat maupun lambat. Dengan keunggulan seperti itu, masyarakat akan mengurangi tingkat pengaruh negatif dari perubahan ini. Arah timbulnya pengaruh pun dapat berasal dari dalam maupun luar. Berikut adalah penjelasan faktor-faktor perubahan sosial berdasarkan arah timbulnya pengaruh.

a. Internal Faktor: Internal faktor (faktor dalam) adalah faktor-faktor yang berasal dari dalam masyarakat itu yang menyebabkan timbulnya perubahan pada masyarakat itu sendiri baik secara individu, kelompok ataupun organisasi. Berikut ini sebab-sebab perubahan sosial yang bersumber dari dalam masyarakat (sebab intern).

b. External Faktor: Selain internal factor, pada masyarakat juga dikenal external factor. External factor atau faktor luar adalah faktor-faktor yang berasal dari luar masyarakat yang menyebabkan timbulnya perubahan pada masyarakat. Berikut ini sebab-sebab perubahan sosial yang bersumber dari luar masyarakat (sebab ekstern).

\section{H. Faktor Pendukung Proses Perubahan}

Terjadinya suatu proses perubahan pada masyarakat, diakibatkan adanya faktor yang mendorongnya, sehingga menyebabkan timbulnya perubahan. Faktor pendorong tersebut menurut Soerjono Soekanto antara lain:

a. Kontak dengan kebudayaan lain

Salah satu proses yang menyangkut hal ini adalah diffusion (difusi). Difusi adalah proses penyebaran unsur-unsur kebudayaan dari individu kepada 
individu lain. Dengan proses tersebut manusia mampu untuk menghimpun penemuan-penemuan baru yang telah dihasilkan. Dengan terjadinya difusi, suatu penemuan baru yang telah diterima oleh masyarakat dapat diteruskan dan disebar luaskan kepada semua masyarakat, hingga seluruh masyarakat akan dapat merasakan manfaatnya. Proses difusi dapat menyebabkan lancarnya proses perubahan, karena difusi mampu memperkaya dan menambah unsurunsur kebudayaan yang seringkali memerlukan perubahan - perubahan dalam setiap lembaga - lembaga kemasyarakatan, yang lama dengan yang baru.

\section{b. Sistem pendidikan formal yang maju}

Pada dasarnya pendidikan memberikan nilai-nilai tertentu bagi individu, untuk memberikan wawasan serta menerima hal-hal baru, juga memberikan bagaimana caranya dapat berfikir secara ilmiah. Pendidikan juga mengajarkan kepada individu untuk dapat berfikir secara obyektif. Hal seperti ini akan dapat membantu setiap manusia untuk menilai apakah kebudayaan masyarakatnya akan dapat memenuhi kebutuhan zaman atau tidak. c. Sikap yang menghargai hasil karya seseorang dan keinginan untuk maju

Bila sikap itu telah dikenal secara luas oleh masyarakat, maka masyarakat akan dapat menjadi pendorong bagi terjadinya penemuan-penemuan baru. Contohnya hadiah nobel, menjadi pendorong untuk melahirkan karyakarya yang belum pernah dibuat.

d. Sikap Toleransi terhadap perbuatanperbuatan yang menyimpang (deviation)

Adanya toleransi tersebut berakibat perbuatan-perbuatan yang menyimpang itu akan melembaga, dan akhirnya dapat menjadi kebiasaan yang terus menerus dilakukan oleh masyarakat.

e. Sistem yang terbuka pada lapisan masyarakat

Adanya sistem yang terbuka di dalam lapisan masyarakat akan dapat menimbulkan terdapatnya gerak sosial vertical yang luas atau berarti memberi kesempatan kepada para individu untuk maju atas dasar kemampuan sendiri. Hal seperti ini akan berakibat seseorang mengadakan identifikasi dengan orangorang yang memiliki status yang lebih tinggi. Identifikasi adalah suatu tingkah laku dari seseorang, hingga orang tersebut merasa memiliki kedudukan yang sama dengan orang yang dianggapnya memiliki golongan yang 
lebih tinggi. Hal ini dilakukannya agar ia dapat diperlakukan sama dengan orang yang dianggapnya memiliki status yang tinggi tersebut.

f. Adanya penduduk yang heterogen

Terdapatnya penduduk yang memiliki latar belakang kelompok-kelompok sosial yang berbeda-beda, misalnya ideologi, ras yang berbeda akan mudah menyulut terjadinya konflik. Terjadinya konflik ini akan dapat menjadi pendorong perubahan-perubahan sosial di dalam masyarakat.

g. Ketidakpuasan masyarakat terhadap bidang-bidang kehidupan tertentu

Terjadinya ketidakpuasan dalam masyarakat, dan berlangsung dalam waktu yang panjang, juga akan mengakibatkan revolusi dalam kehidupan masyarakat.

h. Adanya orientasi ke masa depan

Terdapatnya pemikiran-pemikiran yang mengutamakan masa yang akan datang, dapat berakibat mulai terjadinya perubahan-perubahan dalam sistem sosial yang ada. Karena apa yang dilakukan harus diorientasikan pada perubahan di masa yang akan datang.

\section{Faktor yang Menjadi Penghalang Proses Perubahan}

Di dalam proses perubhan tidak selamanya hanya terdapat faktor pendorong saja, tetapi juga ada faktor penghambat terjadinya proses perubahan tersebut. Faktor penghalang tersebut antara lain:

1. Perkembangan ilmu pengetahuan yang lambat. Terlambatnya ilmu pengetahuan dapat diakibatkan karena suatu masyarakat tersebut hidup dalam keterasingan dan dapat pula karena ditindas oleh masyarakat lain.

2. Sikap masyarakat yang tradisional

Adanya suatu sikap yang selalu membanggakan dan mempertahankan tradisi - tradisi lama dari suatu masyarakat akan berpengaruh pada terjadinya proses perubahan. Karena adanya anggapan bahwa perubahan yang akan terjadi belum tentu lebih baik dari yang sudah ada.

3. Adanya kepentingan yang telah tertanam dengan kuatnya.

Organisasi sosial yang telah mengenal sistem lapisan dapat dipastikan akan ada sekelompok individu yang memanfaatkan kedudukan dalam proses perubahan tersebut. Contoh, dalam masyarakat feodal dan juga pada masyarakat yang sedang mengalami 
transisi. Pada masyarakat yang mengalami transisi, tentunya ada golongan-golongan dalam masyarakat yang dianggap sebagai pelopor proses transisi. Karena selalu mengidentifikasi diri dengan usaha-usaha dan jasajasanya, sulit bagi mereka untuk melepaskan kedudukannya di dalam suatu proses perubahan.

\section{J. Aspek Ekonomi Indonesia}

Dalam halnya berkaitan dengan ketahanan perekonomian bangsa, maka dapat dijabarkan pengertian tentang aspek ekonomi sebagai berikut :

1. Aspek kehidupan nasional yang berkaitan dengan suatu pemenuhan kebutuhan bagi masyarakat meliputi: produksi, distribusi, dan konsumsi barang-barang jasa.

2. Usaha-usaha untuk meningkatkan taraf hidup masyarakat secara individu maupun kelompok, serta cara-cara yang dilakukan dalam setiap kehidupan bermasyarakat untuk memenuhi setiap kebutuhan.

Sistem perekonomian yang
diterapkan oleh suatu negara akan
memberi corak terhadap kehidupan
perekonomian negara yang bersangkutan. Sistem perekonomian liberal dengan orientasi pasar secara murni akan sangat peka terhadap pengaruh-pengaruh dari luar, sebaliknya sistem perekonomian sosialis dengan sifat perencanaan dan pengendalian oleh pemerintah kurang peka terhadap pengaruh-pengaruh dari luar. Perekonomian Indonesia tercantum dalam UUD 1945 Pasal 33. Sistem perekonomian sebagai usaha bersama berarti setiap warga negara mempunyai hak dan kesempatan yang sama dalam menjalankan roda perekonomian dengan tujuan untuk mensejahterakan bangsa. Dalam perekonomian Indonesia tidak dikenal monopoli dan monopsoni baik oleh pemerintah/swasta. Secara makro sistem perekonomian Indonesia dapat disebut sebagai sistem perekonomian kerakyatan. Wujud ketahanan ekonomi tercermin dalam kondisi kehidupan perekonomian bangsa yang mengandung kemampuan memelihara stabilitas ekonomi yang sehat dan dinamis serta kemampuan menciptakan kemandirian ekonomi nasional dengan daya saing tinggi dan mewujudkan kemampuan rakyat. Untuk mencapai tingkat ketahanan ekonomi perlu pertahanan terhadap berbagai hal yang menunjang, antara lain:

a. Sistem ekonomi Indonesia harus mewujudkan kemakmuran dan kesejahteraan yang adil dan merata.

b. Ekonomi kerakyatan menghindari:

1) Sistem Free Fight Liberalism adalah menguntungkan pelaku ekonomi yang kuat. 
2) Sistem Etastisme adalah mematikan potensi unit-unit ekonomi diluar sektor negara.

3) Monopoli adalah akan merugikan masyarakat dan bertentangan citacita keadilan sosial.

c. Struktur ekonomi dimantapkan secara seimbang antara sektor pertanian, perindustrian, dan jasa.

d. Pembangunan ekonomi dilaksanakan sebagai usaha bersama dibawah pengawasan anggota masyarakat memotivasi dan mendorong peran serta masyarakat secara aktif.

e. Pemerataan pembangunan.

f. Kemampuan bersaing.

\section{K. Aspek Sosial Indonesia}

Sosial adalah pergaulan hidup manusia dalam bermasyarakat yang mengandung nilai-nilai keber-samaan, senasib, sepenanggungan, dan solidaritas yang merupakan unsur pemersatu. Adapun aspek-aspek dan faktor-faktor yang mempengaruhi aspek sosial di Indonesia yaitu:

\section{Aspek-Aspek Sosial. Aspek-aspek} sosial dapat dibahas dalam dua dimensi. Pertama, aspek yang dikaitkan dengan lapisan-lapisan kebudayaan yang terdiri dari aspek material, aspek norma-norma (norms) dan aspek nilainilai (values).
- Aspek Kebudayaan Material (Artifacts). Aspek - aspek yang sifatnya material dan dapat diraba atau dilihat secara nyata, seperti pakaian, alat-alat kerja, dan sebagainya. Karena sifatnya adalah material, maka aspek kebudayaan ini relatif cepat berubah.

- Aspek Norma (Norms). Menyangkut kaidah-kaidah atau norma-norma sosial yang mengatur interaksi antara semua warga masyarakat. Aspek ini relatif lebih lambat berubah dibandingkan dengan aspek kebudayaan material.

- Aspek Nilai-Nilai Budaya (Values). Yang berkaitan dengan nilai-nilai luhur yang menjadi pandangan atau falsafah hidup masyarakat. Nilai-nilai inilah yang mendasari norma-norma sosial yang menjadi kaidah interaksi antar warga masyarakat. Aspek nilai inilah paling lambat berubah dibandingkan dengan kedua aspek kebudayaan yang disebut terdahulu.

Kedua, aspek yang dikaitkan dengan bidang-bidang kehidupan sosial masyarakat, yang dalam kegiatan belajar ini dikemukakan bidang kehidupan ekonomi, bidang kehidupan keluarga, dan lembaga-lembaga masyarakat. 
2. Perubahan Sosial dalam Bidang Ekonomi

Pada dasarnya yang menyangkut perubahan-perubahan yang terjadi pada kehidupan masyarakat dalam upaya mereka untuk memenuhi berbagai macam kebutuhan hidupnya, baik perubahan dalam nilai-nilai ekonomi, sikap, hubungan ekonomi dengan warga lainnya, maupun dalam cara atau alat-alat yang dipergunakan. Salah satu kunci dalam perubahan bidang ekonomi ini adalah proses "diferensiasi" dan spesialisasi".

a. Aspek Kehidupan Keluarga. Yang menjadi fokus perhatian adalah perubahan fungsi dan peranan keluarga dalam kaitannya dengan kehidupan masyarakat secara keseluruhan. Perubahan dalam struktur dan jumlah anggota keluarga mendorong terjadinya perubahan fungsi dan peranan keluarga. Salah satu aspek kehidupan keluarga yang paling jelas perubahannya adalah peranan kaum ibu.

b. Aspek Lembaga - Lembaga pada Masyarakat. Perubahan sosial pada dasarnya berkembang, dan dari suasana kehidupan masyarakat tradisional dengan lembagalembaga masyarakat yang jumlah dan sifatnya masih sedikit dan terbatas, serta pada umumnya berdasarkan kegotong-royongan dan kekeluargaan. Berkembang menuju masyarakat yang modern dengan setiap lembaga - lembaga masyarakat yang lebih bervariasi yang pada umumnya dibentuk atas dasar kepentingan warganya, baik dalam bidang ekonomi, kebudayaan, pendidikan, serta dalam bidang hukum, politik dan pemerintahan.

\section{Faktor-Faktor Yang Mempengaruhi Aspek Sosial Indonesia}

1. Faktor Internal: Faktor internal adalah kondisi atau perkembangan yang terjadi dalam lingkungan masyarakat yang bersangkutan yang mendorong perubahan sosial. Faktor-faktor ini yang mencakup terutama faktor-faktor demografis (kependudukan), faktor adanya penemuan-penemuan baru, serta adanya konflik internal dalam masyarakat.

2. Faktor-Faktor Demografis: Semua perkembangan yang berkaitan dengan aspek demografis atau kependudukan, yang mencakup jumlah, kepadatan, dan mobilitas penduduk.

3. Faktor Penemuan-Penemuan Baru 
4. Adanya penemuan di kalangan atau oleh warga masyarakat berkaitan dengan suatu alat atau cara yang selanjutnya diterima penggunaannya secara luas oleh masyarakat, dan oleh karena itulah mempengaruhi perkembangan kehidupan sosial mereka.

5. Faktor Konflik Internal: Pertentangan yang timbul di kalangan warga atau kelompok - kelompok masyarakat sebagai akibat adanya perbedaan kepentingan dan/atau perbedaan persepsi yang dipertahankan oleh masing-masing kelompok.

6. Faktor Eksternal: Faktor Eksternal adalah kondisi atau perkembangan yang terjadi di luar lingkungan masyarakat yang bersangkutan, tetapi secara langsung maupun tidak langsung mempengaruhi perubahan sosial dalam masyarakat yang bersangkutan. Dalam suatu faktor eksternal yang terpenting di antaranya adalah pengaruh lingkungan alam, pengaruh unsur kebudayaan maupun aktualisasi, faktor eksternal juga dapat berupa adanya peperangan yang mengakibatkan akan terjadinya penaklukan suatu masyarakat atau bangsa oleh bangsa lain, yang selanjutnya memaksakan terjadinya perubahan sosial terutama di kalangan bangsa yang kalah perang.

7. Aspek Budaya Indonesia: Budaya adalah sistem nilai yang merupakan hasil hubungan manusia dengan cipta rasa dan karsa yang menumbuhkan gagasan-gagasan utama serta merupakan kekuatan pendukung penggerak kehidupan. Kebudayaan diciptakan oleh faktor organobiologis manusia, lingkungan alam, lingkungan psikologis, dan lingkungan sejarah. Dalam setiap kebudayaan daerah terdapat nilai budaya yang tidak dapat dipengaruhi oleh budaya asing (local genuis). Local genuis itulah pangkal segala kemampuan budaya daerah untuk menetralisir pengaruh negatif budaya asing. Kebudayaan nasional yang merupakan hasil (resultante) interaksi dari budaya-budaya suku bangsa (daerah) atau budaya asing (luar) yang kemudian diterima sebagai nilai bersama seluruh bangsa. Interaksi budaya harus berjalan secara wajar dan alamiah tanpa unsur paksaan dan dominasi budaya terhadap budaya lainnya. Kebudayaan nasional merupakan identitas dan menjadi kebanggaan Indonesia. Identitas bangsa Indonesia adalah manusia dan 
masyarakat yang memiliki sifat-sifat dasar:

a. Religius

b. Kekeluargaan

c. Hidup seba selaras

d. Kerakyatan

Wujud ketahanan sosial budaya tercermin dalam kehidupan sosial budaya bangsa yang dijiwai kepribadian nasional, yang mengandung kemampuan membentuk dan mengembangkan kehidupan sosial budaya manusia dan masyarakat Indonesia yang beriman dan bertakwa kepada Tuhan yang maha esa, bersatu, cinta tanah air, berkualitas, maju dan sejahtera dalam kehidupan yang serba selaras, serasi dan seimbang. Pertumbuhan ekonomi yang tinggi tidak selalu akan mencerminkan distribusi pendapatan yang adil dan merata. Sebab, pertumbuhan ekonomi yang tinggi ini hanya dinikmati oleh sekelompok kecil masyarakat, seperti: masyarakat perkotaan, sedangkan masyarakat pedesaan atau pinggiran mendapat porsi yang kecil dan tertinggal. Kesenjangan di daerah ini semakin diperburuk karena adanya kesenjangan dalam pembangunan antar sektor, terutama antara sektor pertanian (basis ekonomi pedesaan) dan nonpertanian (ekonomi perkotaan).
Ketidakberdayaan

masyarakat pedesaan salah satunya akibat kebijakan yang mismatchdi masa lalu, yaitu kebijakan yang melupakan sektor pertanian sebagai dasar keunggulan komparatif maupun kompetitif. Sesungguhnya pemberdayaan ekonomi masyarakat pedesaan bukan hanya bermanfaat bagi masyarakat pedesaan itu sendiri, tetapi juga membangun kekuatan ekonomi Indonesia berdasarkan kepada keunggulan komparatif dan kompetitif yang dimiliki.

Pembangunan daerah sangat ditentukan oleh potensi yang dimiliki oleh suatu daerah, maka kebijaksanaan yang dibuat oleh pemerintah daerah harus mengacu kepada potensi daerah yang berpeluang untuk dikembangkan, khususnya sektor pertanian. Pada umumnya setiap daerah memiliki potensi yang dapat dikembangkan sebagai pemacu pertumbuhan ekonomi daerah. Potensi yang dimaksud sebagian besar berada di daerah pedesaan. Potensi tersebut antara lain: 1) pengembangan tanaman hortikultura; 2) pengembangan tanaman pada perkebunan; 3) pengembangan usaha perikanan; 4) pengembangan usaha peternakan; 5) pengembangan usaha pertambangan; 6) pengembangan sektor industri; dan 7) potensi keparawisataan. Guna memacu 
pertumbuhan ekonomi di pedesaan, pengembangan sektor pertanian dalam arti luas harus diarahkan kepada sistem agribisnis dan agroindustri, karena pendekatan ini akan dapat meningkatkan nilai tambah sektor pertanian, yang pada hakikatnya dapat meningkatkan pendapatan bagi pelakupelaku agribisnis dan agroindustri di daerah pedesaan. Oleh karena itu, dalam upaya pemberdayaan ekonomii rakyat, keberpihakan masyarakat pada pembangunan sektor agribisnis secara nasional perlu disertai dengan suatu mekanisme yang menjamin bahwa manfaat pembangunan dapat dinikmati oleh rakyat sampai ke pedesaan.

Dari apa yang digambarkan di atas, maka untuk memajukan ekonomi di daerah pedesaan sebagai percepatan pembangunan ekonomi yang berbasis kerakyatan, maka perlu dikembangkan pada kelembagaan ekonomi sebagai sokoguru perekonomian masyarakat. Untuk daerah pedesaan kelembagaan yang dimaksud adalah koperasi yang melibatkan masyarakat pedesaan sebagai anggota. Koperasi tersebut diharapkan dapat sebagai penguat ekonomi pedesaan dan sebagai potensi pasar bagi produk-produk yang dihasilkan oleh masyarakat pedesaan. Di daerah pedesaan bentuk usaha masyarakat pada umumnya pengolahan dari hasil pertanian mereka dalam bentuk usaha kecil atau industri rumah tangga. Dari sisi proses produksi mereka sangat terbatas dalam penguasaan teknologi dan kekurangan modal untuk pengembangan skala usahanya. Begitu juga kekuatan tawar menawar dari hasil produknya sangat rendah. Salah satu untuk meningkatkan kekuatan tawar menawar masyarakat pedesaan adalah melalui lembaga ekonomi pedesaan yaitu koperasi. Pemberdayaan masyarakat pedesaan juga harus mampu memberikan perlindungan yang jelas terhadap masyarakat. Upaya perlindungan dimaksudkan untuk mencegah terjadinya persaingan yang tidak seimbang akibat berlakunya mekanisme pasar dan eksploitasi yang kuat terhadap yang lemah. Kemampuan tawar menawar masyarakat di pedesaan sangatlah lemah, hal tersebut disebabkan karena keterbatasan informasi dan modal kerja dalam berusaha. Masyarakat di pedesaan jelas akan kalah bersaing. Mereka tidak punya apa-apa selain tenaga-tenaga yang pada umumnya kurang terlatih. Dalam pemberdayaan ekonomi masyarakat pedesaan, sektor pertanian harus menjadi sasaran utama. Sektor ini harus dijadikan pijakan yang kokoh sehingga di pedesaan bisa tercapai 
swasembada berbagai produk pertanian.

Akhir-akhir ini pemerintah cukup perhatian terhadap perkembangan ekonomi pedesaan yang melalui pembangunan sektor pertanian yang berorientasi ekspor. Hal ini bertujuan untuk memacu nilai tambah yang tinggi di pedesaan. Aktivitas pembangunan sektor pertanian terutama dalam bentuk skala besar yang dikembangkan melalui program agribisnis dan agroindustri memberikan pengaruh eksternal yang bersifat positif atau bermanfaat bagi wilayah sekitarnya. Manfaat kegiatan pembangunan agribisnis tersebut terhadap aspek ekonomi pedesaan, antara lain: 1) memperluas lapangan kerja dan kesempatan berusaha; 2) peningkatan kesejahteraan masyarakat sekitar; dan 3) memberikan kontribusi terhadap pembangunan daerah. Beberapa kegiatan agribisnis yang secara langsung memberikan dampak terhadap komponen ekonomi pedesaan dan budaya masyarakat sekitar, antara lain: 1) kegiatan pembangunan sumberdaya masyarakat desa; 2) pembangunan sarana prasarana yang dapat dimanfaatkan oleh masyarakat setempat, terutama sarana jalan darat; 3) penyerapan tenaga kerja lokal; 4) penyuluhan pertanian, kesehatan dan pendidikan; dan 5) pembayaran kewajiban perusahaan terhadap negara (pajak-pajak dan biaya kompensasi lain).

Adapun suatu kendala dalam pembangunan ekonomi daerah yang tertinggal, yaitu pembangunan ekonomi pedesaan terutama di daerah yang terpencil (tertinggal) tidak terlepas dari pembangunan sektor pertanian. Kondisi ini disebabkan karena sebagian besar masyarakat pedesaan (sekitar 80\%) mencari nafkah dari sektor pertanian yakni: perkebunan, perikanan, peternakan, kehutanan, tanaman pangan dan hortikultura. Apabila ingin memacu pertumbuhan ekonomi di pedesaan salah satu prioritasnya adalah pengembangan sektor pertanian yang berbasis agribisnis. Untuk jenis agribisnis skala besar seperti perkebunan boleh dikatakan tidak banyak kendala, karena sektor perkebunan yang dikembangkan selama ini berorientasi ekspor yang dikelola oleh perusahan besar. Namun yang jadi masalah adalah pengembangan ekonomi pedesaan dari usaha tani skala kecil yang dikelola secara swadaya oleh masyarakat. Dalam pengembangan sektor pertanian skala kecil tersebut masih ditemui beberapa kendala, terutama dalam pengembangan sistem pertanian yang berbasiskan agribisnis dan agroindustri. 
Kenda-la yang dihadapi dalam pengembangan pertanian khususnya petani skala kecil, antara lain:

a. Lemahnya struktur permodalan dan akses terhadap sumber permodalan. Secara umum pemilikan modal bagi masyarakat pedesan masih relatif kecil, karena modal ini biasanya bersumber daripada penyisihan pendapatan usaha sebelumnya. Untuk memodali usaha selanjutnya masyarakat desa (petani) terpaksa memilih alternatif lain, yaitu meminjam uang pada orang lain yang lebih mampu (pedagang) atau segala kebutuhan usaha tani diambil dulu dari toko dengan perjanjian pembayarannya setelah panen. Kondisi seperti inilah yang menyebabkan petani sering terjerat pada sistem pinjaman yang secara ekonomi merugikan pihak petani.

b. Ketersediaan lahan dan masalah kesuburan tanah. Kesuburan tanah di pedesaan sebagai faktor produksi utama dalam pertanian makin bermasalah. Permasalahannya tersebut bukan saja menyangkut makin terbatasnya lahan yang dapat dimanfaatkan petani, tetapi juga berkaitan dengan perubahan perilaku petani dalam berusaha tani. Dari sisi lain mengakibatkan terjadinya pembagian penggunaan tanah untuk berbagai subsektor pertanian yang dikembangkan oleh petani.

c. Pengadaan dan penyaluran sarana produksi. Sarana produksi sangat diperlukan dalam proses produksi untuk mendapatkan hasil yang memuaskan. Pengadaan sarana produksi di pedesaan itu bukan hanya menyangkut ketersediaannya dalam jumlah yang cukup, tetapi yang lebih penting adalah jenis dan kualitasnya.

d. Terbatasnya kemampuan dalam penguasaan teknologi. Usaha pertanian di pedesaan merupakan suatu proses yang memerlukan jangka waktu tertentu. Dalam proses tersebut akan terakumulasi berbagai faktor produksi dan sarana produksi yang merupakan faktor masukan produksi yang diperlukan dalam proses tersebut untuk mendapatkan keluaran yang diinginkan. Petani yang bertindak sebagai manajer dan pekerja pada usaha taninya haruslah memiliki pengetahuan dan pada keterampilan dalam penggunaan berbagai faktor masukan usaha tani, sehingga mampu memberikan pengaruh terhadap peningkatan produktivitas dan efisiensi usaha yang dilakukan.

e. Lemahnya organisasi yang ada dan manajemen usaha tani. Organisasi 
merupakan wadah yang sangat penting dalam masyarakat, terutama kaitannya dengan penyampaian informasi (top down) dan panya-luran inspirasi (bottom up) para anggotanya. Dalam pertanian organisasi yang tidak kalah pentingnya adalah kelompok tani. Selama ini kelompok tani sudah terbukti menjadi wadah penggerak pengembangan pertanian di pede-saan. Hal ini dapat dilihat dari manfaat kelompok tani dalam hal untuk memudahkan koordinasi, penyulu-han dan pemberian paket teknologi.

f. Kurangnya kuantitas dan kualitas sumberdaya manusia untuk sektor agribisnis. Petani merupakan sumberdaya manusia yang memegang peranan penting dalam menentukan keberhasilan suatu kegiatan usaha tani, karena petani merupakan pekerja dan sekaligus manajer dalam usaha tani itu sendiri. Ada dua hal yang dapat dilihat berkaitan dengan sumberdaya manusia ini, yaitu jumlah yang tersedia dan kualitas sumberdaya manusia itu sendiri. Kedua hal ini sering dijadikan sebagai indikator dalam menilai permasalahan yang ada pada kegiatan pertanian. Adapun program pembangunan daerah tertinggal, dengan sejalan dengan pengembangan ekonomi Indonesia yang bertumpu kepada ekonomi kerakyatan, maka pemerintah yang ada di kabupaten / kota melakukan pembangunan ekonomi harus berbasis pada kerakyatan. Setiap Pembangunan ekonomi terutama di pedesaan dalam rangka mengangkat marwah, derajat, harkat, martabat masyarakat pedesaan sebagai upaya mewujudkan program pengetasan kemiskinan, meningkatkan kualitas sumberdaya manusia pedesaan dan pembangunan infrastruktur sebagai penunjang mobiltas barang dan penduduk desa-kota. Dalam upaya memacu pembangunan dari sisi aspek ekonomi dan sosial di daerah tertinggal, maka program pembangunan pedesaan harus memproritaskan ketiga aspek tersebut.

\section{Peningkatan Ekonomi Rakyat (Mengatasi Kemiskinan)}

Program pengetasan kemiskinan merupakan pendekatan pembangunan yang bersifat komprehensif dan mendasar dalam tataran kesejahteraan dan harkat yang manusiawi, oleh karena sekalipun kemiskinan merupakan fenomena ekonomi namun memberikan konsekwensi yang kuat terhadap berbagai aspek kehidupan 
masyarakat sehingga mengaki-batkan masyarakat yang mengalami kemiskinan tersebut menjadi rendah nilai-nilai kemanusiaannya sehingga dalam kehidupannya kurang bermarwah. Khusus untuk daerah tertinggal, pemilikan aset produktif seperti lahan sangat tidak adil.

Hal ini menyebabkan terjadinya ketimpangan pendapatan bagi masyarakat pedesaan. Dari hasil pengamatan terlihat penguasaan asset produktif (lahan) di pedesaan lebih banyak dikuasai oleh perusahaan-perusahaan besar dan orang kota. Dampak dari semuanya ini terhadap mekanisme pasar yang dipengaruhi secara signifikan oleh aspek permodalan dan kebijakan yang kurang berpihak kepada masyarakat miskin. Masyarakat lebih banyak berhadapan dengan pasar yang bersifat monopsoni.

\section{N. Peningkatan Kualitas Sumberdaya Manusia (Pengetasan Kebodohan)}

Kebodohan sebagai cerminan dari rendahnya mutu sumberdaya manusia (SDM). Kualitas SDM sangat menentukan perubahan dan percepatan pembangunan disuatu daerah. Apabila kualitas SDM rendah, maka masyarakat akan sulit menerima perubahan, mereka tidak mampu untuk mengikuti perubahan baik dari sisi pembangunan maupun dari sisi kemajuan ekonomi. Mutu SDM yang rendah akan berdampak pada rendahnya tingkat keterampilan dan penguasaan teknologi. Individu ataupun kelompok masyarakat yang mengalami kondisi ini akan selalu menjadi objek pembangunan dan sangat terbatas kemampuannya untuk menjadi subjek yang berperan secara aktif dalam pembangunan. Pembangunan infrastruktur sangat diperlukan untuk melancarkan dan untuk mensukseskan pencapaian berbagai tujuan dan keinginan di berbagai aspek kehidupan, terutama untuk mengentaskan kemiskinan dan mengatasi kebodohan. Pembangunan infrastruktur akan meningkatkan mobilitas manusia dan barang antar daerah dan antara kabupaten/kota.

Peningkatan ini hendaknya tidak saja melalui kuantitas tetapi juga kualitasnya yang meliputi fasilitas transportasi (jalan, jembatan, pelabuhan), fasilitas kelistrikan, fasilitas komunikasi, fasilitas pendidikan, dan fasilitas air bersih. Tersedianya infrastruktur yang memadai akan dapat mengembangkan potensi sumberdaya manusia (SDM) dan potensi sumberdaya alam (SDA) secara optimal dan dapat mengeliminasi kesenjangan antar kelompok masyarakat, antar wilayah kabupaten/kota, serta antara pedesaan dengan perkotaan.

\section{O. Kesimpulan}

Suatu perubahan social dalam kehidupan masyarakat dipengaruhi oleh beberapa faktor yang bertindak sebagai 
pendukung dan penghambat jalannya proses perubahan sosial tersebut. Faktor-faktor tersebut dapat berasal dari dalam masyarakat itu sendiri (internal factor) serta juga dapat berasal dari luar lingkupan masyarakat (External factor). Faktor-faktor yang berhubungan dengan perubahan masyarakat berdasarkan arah antara lain, Internal Faktor yang di dalamnya terdapat pelbagai faktor, Dinamika Penduduk, Penemuan-penemuan baru, akan Munculnya pertentangan, dan Terjadinya Pemberontakan.

Sedangkan faktor yang kedua adalah External Factor, terdiri dari Bencana pada Alam, Perang dan Kebudayaan masyarakat lain. Faktor pendukung perubahan social antara lain, kontak dengan kebudayaan lain, sistem pendidikan formal yang maju, sikap menghargai hasil karya seseorang dan keinginan untuk maju, toleransi terhadap perbuatan-perbuatan yang menyimpang (deviation), sistem terbuka pada lapisan masyarakat, adanya penduduk yang heterogen, ketidakpuasan masyarakat terhadap bidang-bidang kehidupan tertentu dan adanya orientasi ke masa depan. Faktor penghambat perubahan social antara lain, perkembangan ilmu pengetahuan yang lambat, sikap masyarakat yang tradisional, adanya kepentingan yang telah tertanam dengan kuatnya, kurangnya hubungan dengan masyarakat lain, adanya prasangka buruk terhadap hal-hal baru, adanya hambatan yang bersifat ideologis dan adat atau kebiasaan.

\section{P. Daftar Pustaka}

Abdullah Nashih Ulwan. (1995). Pendidikan Anak Dalam Islam 2. Jakarta: Pustaka Amani.

Alo Liliweri. (1997). Komunikasi Antarpribadi. Bandung: PT. Citra Aditya Bakti.

Dedy Mulyana dan Jalaluddin Rakhmad. (2001). Komunikasi Antar Budaya. Bandung: Remaja Rosdakarya.

H.A Mustofa. (1997). Akhlak Tasawuf. Bandung: CV. Pustaka Setia

Hafied Cangara. (1998). Pengantar IImu Komunikasi. Jakarta: PT. Raja Grapindo Persada.

H. Mafri Amir. (1999). Etika Komunikasi Masa Dalam Pandangan Islam. Jakarta: Logos.

Hussein Bahreisj. (1981). Ajaran-Ajaran Akhlak Imam Ghazali. Surabaya: Al Ikhsan.

Jalaluddin . (2000). Psikologi Agama. Jakarta: PT Raja Grafindo Persada.

Onong Uchyana Effendy. (2001). IImu Komunikasi. Bandung: Remaja Rosdakarya. 
Sudarsono. (1993). Etika Islam Tentang

Kenakalan Remaja. Jakarta: PT

Rineka Cipta 